\title{
Towards Addressing Primary Education Crisis in North-East Nigeria
}

\author{
Imrana Alhaji Buba* \\ Centre of African Studies, University of Edinburgh, UK
}

Submission: January 04, 2019; Published: February 21, 2019

"Corresponding author: Imrana Alhaji Buba, Centre of African Studies, University of Edinburgh, UK

\section{Policy Brief}

\section{Executive Summary}

a) Nigeria has the highest number of out of school children in the world, and most of its primary schools are ill-equipped [1].

b) Low levels of education in north-east Nigeria have also been exacerbated by the Boko Haram insurgency, as a result of which 1,400 schools were damaged, more than one million children forced out of school, while 2,295 teachers have been killed $[1,2]$.

c) Primary education is a basic right and its availability in post-conflict communities can provide life- saving information, protect children from trafficking, and recruitment by armed groups.

d) Considerable effort is needed to ensure that children deprived of educational facilities as a result of the Boko Haram insurgency are given access to alternative schools, as well as develop a long- term programme together with the Nigerian government and local communities to rehabilitate the education sector in the region.

\section{Background}

This policy brief examines problems related to lack of access to primary education in Nigeria's conflict-ridden north-eastern region, and highlights some of the reasons why it should be a key concern to Nigeria's international development partners. It also provides recommendations on how to address this pressing matter with the objective of improving access to quality primary education in north-eastern Nigeria. Although basic education is 'free and compulsory', Nigeria's out-of-school population is the largest in the world-of the 57 million worldwide who are not receiving a formal education, more than 10 million live in Nigeria [3].

The free education policy in Nigeria only implies that no "school fee", which means there are several levies imposed by schools as well as other costs (like uniform, books, and transportation) that pose a significant barrier to many children in accessing primary education. Another issue of concern is the serious disparities of access to education across different regions in Nigeria.

The situation is particularly bleak in the north-east, a region that has the lowest rate of school attendance and most of its schools are ill-equipped [4]. Literacy levels in the north-east are the lowest in the country, with 91 and 72 percent unable to read after completing grades 4 and 6, respectively, and 29 percent unable to do simple arithmetic after completing primary education [5]. This is even more worrisome among female children [6]. For example, the most recent data from the National Population Commission indicates that $85 \%$ of female children in the North East cannot read at all, compared with $20 \%$ in the South West [7].

Boko Haram Insurgency and the Education Crisis in North-east Nigeria

Boko Haram insurgency in North-east region further devastated an already bad education system characterized by a severe lack of infrastructure, qualified teachers, teaching materials and overcrowded classrooms. Human Rights Watch reported that as a result of the incessant attacks, over 1,400 schools were destroyed, damaged or looted, more than one million children have been forced out of school, including 600,000 who have lost all access to education [2]. While 2,295 teachers have been killed and over 19,000 forced to flee [1]. The abduction by Boko Haram of 276 schoolgirls (113 are still in captivity) shocked the world and attracted global attention on the impact of the insurgency on education.

In addition to the strategic attacks, the insurgents have also used schools for various purposes in areas where they temporarily seized control, including to detain captives and store looted properties. Also, research shows that between 2013 and 2015 many schools were forced to shut down and the deserted school buildings were converted into shelters for internally displaced persons or military camps, further reducing children's right to education [4]. In some cases, the insurgents apparently attacked the schools because of the presence of the military. 
Although Boko Haram insurgency has been 'technically defeated' and there has been some improvement in the last 2 years, there are still significant barriers to primary education for many children in north-eastern Nigeria. The education needs are overwhelming both in IDP camps and in host communities, where more than $50 \%$ is under the age of 18 [5]. Some informal learning centres are established, but they are not enough to cater for all the children in need. In its Joint Education Needs Assessment for Northeast Nigeria, ACAPS reported that school attendance has been affected mostly in rural areas as they lack teaching and learning materials, teaching aids, and teachers, unlike in urban areas, where the schools relied on temporary classrooms and volunteer teachers [8]. The inadequacy of qualified teachers means that those still working are overburdened with the workload of overpopulated and ill-equipped classrooms.

\section{The Education Response So Far}

Although the North-east region's education needs are overwhelming, the education sector has so far received limited funding and there are only a few international development partners currently implementing education programmes. The North-East Nigeria Recovery and Peace Building Assessment (RPBA) gives a total figure for damages to education infrastructure within the three states of Adamawa, Borno, and Yobe at 249 million USD; and 721 million USD as the estimated needs for education recovery in the 6 north-east states [9]. Funding constraints remains the biggest challenge for agencies to scale up and expand coverage; only $27 \%$ of the 2016 Humanitarian Response Plan targeted school-aged children have been reached with education support, leaving as many as $73 \%$ of the target group behind [5]. The economic burden on the Nigerian government of managing the Boko Haram insurgency has been disastrous, and the huge spending on security has had a ripple effect on the educational sector.

While development partner's commitment to helping Nigeria overcome its challenges is worthy of commendation, it does appear that their response to the education crisis in north-eastern Nigeria has been small relative to the overwhelming support offered to other sectors and/or regions. Most of the interventions are focused on providing temporary classrooms in IDPs camp and supply of basic educational materials like school bags and books, while the more sustainable educational programmes are mostly located outside the affected states. For example, the USAIDfunded Northern Education Initiative (NEI) that aims to increase access to education for orphans and vulnerable children covered two northern states- Bauchi and Sokoto-whose schools are not affected by the insurgency. Also, DFID's major education projects in Nigeria: The Education Sector Support Programme in Nigeria (ESSPIN) and the Girls' Education Project (GEP) did not cover most states in north-eastern Nigeria. For example, none of the six north-eastern Nigerian states is part of the ESSPIN and only Bauchi and Borno states are included in the GEP. Although the North-East Transition to Development Programme is the largest
DFID Nigeria's planned programmes in 2017/18 [10], there is no clear emphasis on improving the quality of education. The story is the same with many other donor-funded programmes in northeast Nigeria.

\section{Recommendations}

a) Education is a basic right and its availability in postconflict communities can provide life-saving information, protect children from trafficking, and recruitment by armed groups. Considerable effort is needed to ensure that children deprived of educational facilities as a result of the Boko Haram insurgency are given access to quality education. Specifically:

b) Development partners should encourage and financially support Nigerian government's effort to ensure that humanitarian education response plans are adequately funded so that interruptions to education caused by the insurgency are minimised. Develop a long- term programme on education in north- east that takes a more holistic and comprehensive approach to rehabilitate and reboot the education sector in the region.

c) If providing support for the reconstruction of schools or the education sector generally, development partners should urge the Nigerian government to adopt strong protections for schools from military use. They should support the government's Safe Schools Initiative, that is aimed at bolstering the security of schools and monitoring the quality of education in partnership with community groups.

d) Integrated Qur'anic education (Tsangaya School Programme) was well received by many communities in north-east Nigeria. Thus, it can help in increasing school enrolment, particularly in rural areas. Also, such intervention will resonate with the Nigerian government's policy to expand Integrated Qur'anic education, to provide basic literacy and numeracy for as many children as possible. Operating under a conducive policy environment will facilitate project implementation.

e) It is clear from many successful donor-funded programmes in Nigeria that collaborative interventions with local communities have a more positive impact. Thus, collaboration with community members in such interventions, for example, engaging local skilled workers to make uniforms or school bags can help localise solutions and build a sense of responsibility.

\section{References}

1. UNICEF (2017) 'More than half of all schools remain closed in Borno State, epicentre of the Boko Haram crisis in northeast Nigeria'. Nigeria.

2. Human Rights Watch (2016) They Set the Classrooms on Fire: Attacks on Education in Northeast Nigeria. Nigeria.

3. The Guardian (2014) 'Nigeria's girls and the struggle for an education in the line of fire'. 15 May 2014. Nigeria. 
4. Isokpan, AJ, Durojaye, E (2016) Impact of the Boko Haram Insurgency on the Child's Right to Education in Nigeria. PER / PELJ 1(19).

5. Save the Children (2016) Building a Safe and Prosperous Future for Nigeria's Children Through Education. November 2016, Nigeria.

6. Joda, FM, Abdulraheed, O (2015) Effects of Insurgency on Girls Education in North Eastern Nigeria. European Journal of Education and Development Psychology 3(1): 44-50.

7. National Population Commission (2011) Demographic Household Education Data Survey 2010: Education Data for Decision- making (May 2011). USA.
8. ACAPS (2017) Joint Education Needs Assessment Northeast Nigeria. Nigeria.

9. Mariam, Masha et al. (2016) North-East Nigeria - Recovery and Peace Building Assessment. Washington, D.C. World Bank Group. USA.

10. DFID (2017) DFID Nigeria Profile: July 2017. Policy Paper. Nigeria.
This work is licensed under Creative Commons Attribution 4.0 License DOI: 10.19080/ASM.2019.03.555602 